\title{
Peer review and compliance with international anti-corruption norms: Insights from the OECD Working Group on Bribery
}

\author{
Hortense Jongen* \\ Faculty of Social Sciences, Department of Political Science and Public Administration, Vrije Universiteit Amsterdam, \\ The Netherlands \\ ${ }^{\star}$ Corresponding author. Email: h.j.e.m.jongen@vu.nl
}

(Received 27 March 2020; revised 3 February 2021; accepted 5 February 2021; first published online 16 March 2021)

\begin{abstract}
How can we make sure that states do not only sign international anti-corruption conventions, but also comply with them once the ink has dried? Peer review among states offers one answer to this question. This article develops a theoretical framework to study the different processes and mechanisms through which peer reviews can contribute to state compliance. It focuses on three processes: transparency, pressure, and learning. The article subsequently applies this framework to the OECD Working Group on Bribery (WGB) in order to identify how far participants in this peer review perceive the WGB as capable of organising these processes, and to what extent they consider these processes relevant for promoting state compliance. Data come from an online survey (74 observations) and 17 in-depth interviews. The findings reveal that this peer review exercise is perceived as effective in creating transparency about state behaviour, mobilising pressure, and stimulating learning. However, the extent to which these processes can promote compliance is more limited. For these processes to work, political will is crucial.
\end{abstract}

Keywords: Bribery; Compliance; Corruption; Monitoring; OECD; Peer Review

\section{Introduction}

How can we make sure that states do not only sign international anti-corruption conventions, but also take action once the ink has dried? Peer review among states offers one answer to this question. Used extensively in the international anti-corruption regime, peer reviews aim to promote reforms in countries by means of mutual intergovernmental evaluations; experts from member states periodically evaluate each other's compliance with international anti-corruption agreements and make recommendations for improvement. ${ }^{1}$ While these instruments usually cannot sanction states that disregard their recommendations, peer reviews do hold potential to raise compliance levels in states. Notably, they aim to create transparency about states' performance, mobilise peer and public pressure, and promote learning during the evaluations. ${ }^{2}$ Today, many

\footnotetext{
${ }^{1}$ Fabricio Pagani, 'Peer review as a tool for cooperation and change', African Security Review, 11:4 (2002), pp. 15-24.

${ }^{2}$ Valentina Carraro, Thomas Conzelmann, and Hortense Jongen, 'Fears of peers? Explaining peer and public shaming in global governance', Cooperation and Conflict, 54:3 (2019), pp. 335-55; Hortense Jongen, 'The authority of peer reviews among states in the global governance of corruption', Review of International Political Economy, 25:6 (2018), pp. 909-35; Markku Lehtonen, 'OECD environmental performance review programme: Accountability (f)or learning?', Evaluation, 11:2 (2005), pp. 169-88; Pagani, 'Peer review'; Claudio Radaelli, 'Europeanization, policy learning, and new modes of governance', Journal of Comparative Policy Analysis: Research and Practice, 10:3 (2008), pp. 239-54; Rik de Ruiter, 'Full

(C) The Author(s), 2021. Published by Cambridge University Press on behalf of the British International Studies Association. This is an Open Access article, distributed under the terms of the Creative Commons Attribution licence (http://creativecommons.org/licenses/by/4.0/), which permits unrestricted re-use, distribution, and reproduction in any medium, provided the original work is properly cited.
} 
international organisations rely on peer reviews to tackle transnational policy problems such as sustainable development, trade, and money laundering.

Yet, despite their extensive use, we know little about the extent to which and how peer reviews effectively create transparency, generate pressure, and promote mutual learning. Even more so, do participants in these peer reviews consider such soft governance processes at all relevant for promoting compliance with international anti-corruption norms? While a recent body of research studies peer reviews through the lenses of authority, ${ }^{3}$ politicisation, ${ }^{4}$ and process performance, ${ }^{5}$ only a limited number of studies analyse the instrument's relevance for state compliance. Of those that do, several investigate the domestic factors that explain the impact of peer reviews and related instruments, which include case-based analyses of individual countries. ${ }^{6}$ Few pay explicit attention to the international level, notably: how peer reviews operate, the dynamics that take place in them, and the processes and mechanisms through which they seek to promote compliance. ${ }^{7}$ One exception is a study on compliance in the area of human rights. ${ }^{8}$ Focusing on the comparatively understudied policy field of corruption control, ${ }^{9}$ this article aims to fill this gap by pursuing two aims: (1) To identify to what extent peer review is perceived as capable of creating transparency, generating pressure, and promoting learning; and (2) to explore how far these processes are regarded as relevant in promoting compliance with international anti-corruption norms.

In doing so, this article makes several contributions. Theoretically, it contributes a novel framework that outlines the different processes and mechanisms through which peer reviews can promote compliance with international norms. It focuses on three key processes: creating transparency, organising pressure, and promoting learning. The framework takes inspiration from two strands in the literature: research on compliance with international norms and research on peer reviews. It first reviews different reasons for compliance with international law that are rooted in three theoretical perspectives: an enforcement, management, and constructivist

disclosure? The Open Method of Coordination, parliamentary debates and media coverage', European Union Politics, 14:1 (2013), pp. 95-114.

${ }^{3}$ Valentina Carraro and Hortense Jongen, 'Leaving the doors open or keeping them closed? The authority of peer reviews in international organizations', Global Governance, 24:4 (2018), pp. 615-35; Jongen, 'The authority of peer reviews among states'.

${ }^{4}$ Valentina Carraro, 'The United Nations treaty bodies and Universal Periodic Review: Advancing human rights by preventing politicization?', Human Rights Quarterly, 39:4 (2017), pp. 943-70; Rochelle Terman and Erik Voeten, 'The relational politics of shame: Evidence from the Universal Periodic Review', The Review of International Organizations, 13:1 (2018), pp. 1-23.

${ }^{5}$ Jan Karlas and Michal Parízek, 'The process performance of the WTO Trade Policy Review Mechanism: Peer-reviewing reconsidered', Global Policy, 10:3 (2019), pp. 376-84.

${ }^{6}$ Christos L. Fasois, 'Mechanisms of policy learning in the European Semester: Pension reforms in Belgium', in Claire A. Dunlop, Claudio M. Radaelli, and Philipp Trein (eds), Learning in Public Policy (New York, NY: Springer Berlin Heidelberg, 2018), pp. 75-96; Martin Heidenreich and Jonathan Zeitlin (eds), Changing European Employment and Welfare Regimes: The Influence of the Open Method of Coordination on National Reforms (London and New York: Routledge, 2009); Sojin Lim, 'Compliance with international norms: Implementing OECD DAC principles in South Korea', Globalizations, 11:6 (2014), pp. 859-87; Thenia Vagionaki, 'Blocked learning in Greece: The case of soft-governance', in Dunlop, Radaelli, and Trein (eds), Learning in Public Policy Learning in Public Policy, pp. 191-214.

${ }^{7}$ Several studies analyse the international conditions under which these processes take shape: Carraro, Conzelmann, and Jongen, 'Fears of peers'; Jongen, 'The authority of peer reviews among states'; De Ruiter investigates the conditions under which the European Union's Open Method of Coordination generates pressure on states ('Full Disclosure?').

${ }^{8}$ Valentina Carraro, 'Promoting compliance with human rights: The performance of the United Nations' Universal Periodic Review and treaty bodies', International Studies Quarterly, 63:4 (2019), pp. 1079-93.

${ }^{9}$ Several studies offer descriptive accounts of peer reviews in the area of anticorruption. While these studies provide a good starting point for the present analysis, they offer limited insight into how peer reviews might contribute to compliance: for example, Nicola Bonucci, 'Article 12: Monitoring and follow-up', in Mark Pieth, Lucinda Low, and Nicola Bonucci (eds), The OECD Convention on Bribery: A Commentary (Cambridge: Cambridge University Press, 2014), pp. 534-76; Anja Jakobi, 'The OECD and crime: The fight against corruption and moneylaundering', in Kerstin Martens and Anja Jakobi (eds), Mechanisms of OECD Governance (Oxford and New York: Oxford University Press, 2010), pp. 139-62. 
perspective. The article subsequently connects this discussion to the different processes and mechanisms through which peer reviews can affect state behaviour and contribute to compliance.

Empirically, the article offers a systematic, empirical analysis of how transparency, pressure, and learning take shape in peer reviews and can contribute to compliance with international anti-corruption norms. Drawing upon data from a survey and 17 qualitative interviews, it applies the theoretical framework to the Organisation for Economic Cooperation and Development (OECD) Working Group on Bribery (WGB). Since 1999, the WGB has reviewed states' performance under the OECD Convention against Foreign Bribery, the first multilateral legal instrument in the fight against foreign bribery. What makes the WGB an interesting case is that it does not only evaluate states' legal and practical implementation of an anti-corruption agreement. It also reviews compliance, that is, whether states investigate allegations of foreign bribery and prosecute companies that have violated anti-bribery laws. Other peer reviews in the anti-corruption regime, such as the Council of Europe's Group of States against Corruption (GRECO) and the Implementation Review Mechanism of the United Nations Convention against Corruption (UNCAC), do not review state compliance. According to Transparency International, the world's leading anti-corruption Non-Governmental Organisation, the WGB is the 'gold standard of monitoring' in the anti-corruption regime. ${ }^{10}$ Hence, this peer review offers a most-likely case to trigger processes of transparency, to exert pressure, and to promote learning about how to fight foreign bribery effectively. If the WGB faces difficulties in this regard, other anti-corruption peer reviews most likely do so as well.

The next section introduces the compliance debate in international law and international relations, and details the theoretical framework. After introducing data and methods (section 2), section 3 outlines the WGB's history and working procedures. Section 4 then investigates the extent to which the WGB is perceived to create transparency of state behaviour, to generate pressure, and to promote learning. The findings demonstrate that the WGB is perceived as effective in doing so. The analysis in section 5 , however, reveals that the extent to which these processes can address non-compliance is considered to be more limited. While the three peer review processes can support states in complying with the Convention, political will is crucial for them to be effective.

\section{Peer review as a mode of governance}

More than two decades ago, peer review made its entrance as a new way of governing complex transnational policy problems. Its extensive use in international organisations as diverse as the African Union, the Council of Europe, the European Union, the Organisation of American States, and the United Nations has attracted substantial academic interest. As mentioned in the introduction, several studies have investigated the international conditions under which different peer review processes take shape. Others have sought to explain the domestic impact of these practices in individual countries. However, hardly any research focuses specifically on the relevance of processes that are organised at the international level for state compliance.

This gap in the literature is perhaps unsurprising, as it is difficult to establish a causal relationship between international peer review processes and domestic reforms. Simply because states change their policies in line with a peer review's recommendations does not mean that the review exercise caused this. States might have already intended to implement these reforms for reasons exogenous to the peer review. In addition, states' anti-corruption legislation and efforts are simultaneously under review by various monitoring bodies, which makes it difficult to identify who gave the decisive push for policy reform, if this can be attributed to a single actor at all.

Recognising these limitations, this article does not conduct an objective, external assessment of whether peer review in the WGB has triggered reforms in states. Instead, it analyses the

\footnotetext{
${ }^{10}$ See: $\{$ http://www.oecd.org/corruption/anti-bribery/anti briberyconvention/oecdworkinggrouponbriberyininternationalbusinesstransactions.htm $\}$ accessed 30 November 2020.
} 
perceptions of OECD secretariat officials and state delegates, a methodological choice that is further explained in section 2. The next section first discusses the concept of compliance and reviews different perspectives on what explains (non-)compliance with international norms. Subsection 1.2 subsequently introduces the theoretical framework, which details the different processes and mechanisms through which peer reviews are expected to contribute to compliance.

\subsection{Compliance with international law}

Why states do or do not comply with international agreements has interested students of international relations and international law for almost two decades. ${ }^{11}$ The academic literature distinguishes between treaty implementation, compliance, and effectiveness. Implementation refers to 'the adoption of domestic rules or regulations that are meant to facilitate, but do not in themselves constitute, compliance with international agreements' ${ }^{12}$ It concerns the legal and institutional framework that is designed to put an international agreement into practice. Compliance goes one step beyond implementation. ${ }^{13}$ It pertains to the extent to which states also adhere to their international commitments in practice and how far their behaviour falls in line with prescribed norms. ${ }^{14}$ In the case of the WGB, this concerns the domestic enforcement of the Anti-Bribery Convention, that is, whether states open investigations into (alleged) bribery cases, start criminal proceedings, and impose sanctions. Finally, effectiveness concerns a peer review's efficacy in addressing a policy problem, such as reducing corruption levels. ${ }^{15}$ Absent reliable indicators on the scope of international bribery, a peer review's effectiveness in fighting bribery is difficult to determine. While some countries make data and statistics available on prosecutions and settlements (that is, compliance), we know little about the extent to which this has also deterred multinational companies from paying bribes abroad (that is, effectiveness). ${ }^{16}$

Three strands in the compliance literature present contending claims about what determines compliance with international law. The first, the enforcement perspective, takes a rationalist approach and emphasises incentive structures and cost-benefit calculations. ${ }^{17}$ States are considered rational actors that will comply with international agreements when the benefits of

\footnotetext{
${ }^{11}$ Tanja A. Börzel, Tobias Hoffmann, Diana Panke, and Carina Sprungk, 'Obstinate and inefficient: Why member states do not comply with European Law', Comparative Political Studies, 43:1 (2010), pp. 1363-90; Jeffrey T. Checkel, 'Why comply? Social learning and European identity change', International Organization, 55:3 (2001), pp. 553-8; George W. Downs and Michael A. Jones, 'Reputation, compliance and international law', Journal of Legal Studies, 31 (2002), pp. S95-S114; George W. Downs, David M. Rocke, and Peter N. Barsoom, 'Is the good news about compliance good news about cooperation?', International Organization, 50:3 (1996), pp. 379-406; Beth A. Simmons, 'Compliance with international agreements', Annual Review of Political Science, 1:1 (1998), pp. 75-93; Simmons, 'International law and state behavior: Commitment and compliance in international monetary affairs', American Political Science Review, 94:4 (2000), 819-35; Jonas Tallberg, 'Paths to compliance: Enforcement, management and the European Union', International Organization, 56:3 (2002), pp. 609-43; Esther Versluis and Erika Tarr, 'Improving compliance with European Union law via agencies: The case of the European Railway Agency', Journal of Common Market Studies, 51:2 (2013), pp. 316-33.

${ }^{12}$ Simmons, 'Compliance with international agreements', pp. 77-8.

${ }^{13}$ While treaty implementation often precedes compliance, compliance may occur for reasons unrelated to an international treaty.

${ }^{14}$ Simmons, 'International law and state behavior'.

${ }^{15}$ Oran R. Young, 'Effectiveness of international environmental regimes: Existing knowledge, cutting-edge themes, and research strategies', Proceedings of the National Academy of Sciences, 108:50 (2011), pp. 19853-860.

${ }^{16}$ One exception is a survey experiment conducted in Vietnam, which finds that multinational companies that are subject to the OECD Anti-Bribery Convention show reduced bribery activity as compared to multinationals from non-signatory states: Nathan M. Jensen and Edmund J. Malesky, 'Nonstate actors and compliance with international agreements: An empirical analysis of the OECD Anti-Bribery Convention', International Organization, 72:1 (2018), pp. 33-69. Due to the lack of data available on a large sample of countries, an analysis of effectiveness is outside of the present article's scope.

${ }^{17}$ Downs and Jones, 'Reputation, compliance and international law'; Downs, Rocke, and Barsoom, 'Is the good news about compliance, good news about cooperation?'.
} 
compliance outweigh its costs. The costs of (non-)compliance can be material (for example, the human and financial resources that states need to invest to enforce legislation domestically) or social (for example, damage to a country's international standing). The second strand in the literature, the management school, offers a different explanation for why states comply with international agreements. Managerial theorists hold that non-compliance is often inadvertent rather than a calculated decision. ${ }^{18}$ States are generally inclined to comply with the agreements they have signed, but might fail to do so because they lack the capacity or resources to implement an agreement. Inadequate clarity of international commitments, due to ambiguous treaty language, is another reason why states do not always comply. Finally, constructivists add a third perspective to the compliance debate. ${ }^{19}$ They contend that states are positively predisposed to compliance with international agreements, as long as these norms are regarded as legitimate. ${ }^{20}$ Compliance then becomes the right and appropriate thing to do. ${ }^{21}$

As each strand in the compliance literature identifies different reasons for states' (lack of) compliance with international agreements, they also suggest different policy interventions to raise compliance levels. The enforcement literature attaches the most importance to monitoring and sanctioning. By increasing the chances that shirking will be detected, exposed, and punished, these mechanisms can alter states' incentives to defect. Managerial theorists, in turn, assert that sanctions are ineffective at best - and counterproductive at worst - in instances where noncompliance is involuntary. ${ }^{22}$ Instead, they suggest measures to increase the transparency of states' performance, to promote the interpretation of international rules, and to build capacity. ${ }^{23}$ Finally, constructivists emphasise the importance of social learning and socialisation processes. Through social interactions in international environments, involved actors might change their beliefs about appropriate behaviour, readjust their preferences, and internalise new norms. ${ }^{24}$ Table 1 summarises the three perspectives on compliance with international norms.

While these three strands in the compliance literature start from different theoretical assumptions, several scholars argue that they should not be seen as competing or mutually exclusive, but that they can complement each other. ${ }^{25}$ In fact, combining different compliance strategies and instruments might yield more effective compliance systems. ${ }^{26}$ As will be discussed in the next section, peer reviews hold considerable potential in this regard.

\footnotetext{
${ }^{18}$ Abram Chayes and Antonia Chayes, The New Sovereignty: Compliance with International Regulatory Agreements (Cambridge and London: Harvard University Press, 1995); Abram Chayes, Antonia Chayes, and Ronald Mitchell, 'Managing compliance: A comparative perspective', in Edith Brown Weiss and Harold Jacobsen (eds), Engaging Countries: Strengthening Compliance with International Environmental Accords (Cambridge and London: MIT Press, 1998); Harold H. Koh, 'Why do nations obey international law?', The Yale Law Journal, 106 (1997), pp. 2599-659.

${ }^{19}$ Several scholars refer to this as the 'legitimacy perspective' (for example, Börzel et al., 'Obstinate and inefficient'; Versluis and Tarr, 'Improving compliance') or 'persuasion', for example, Miriam Hartlapp, 'On enforcement, management and persuasion', Journal of Common Market Studies, 45:3 (2007), pp. 653-74.

${ }^{20}$ Simmons, 'Compliance with international agreements'. This is additionally strengthened by the normative belief that foreign bribery is unethical, and that states should therefore comply with international legislation that criminalises this offence.

${ }^{21}$ Johan P. Olsen and James G. March, 'The Logic of Appropriateness', ARENA Working Papers, No. 9 (2004).

${ }^{22}$ Chayes and Chayes, The New Sovereignty.

${ }^{23}$ See, for example, Tallberg, 'Paths to compliance'.

${ }^{24}$ Checkel, 'Why comply?'; Jeffrey T. Checkel, International Institutions and Socialization in Europe (New York: Cambridge University Press, 2007); Alastair Johnston, 'Treating international institutions as social environments', International Studies Quarterly, 45:4 (2001), pp. 487-515.

${ }^{25}$ See also Börzel et al., 'Obstinate and insufficient'; Carraro, 'Promoting compliance with human rights'; Hartlapp 'On enforcement'; Tallberg, 'Paths to compliance'; Versluis and Tarr, 'Improving compliance'.

${ }^{26}$ Tallberg, for instance, puts forward the proposition that 'compliance systems become most effective when combining enforcement and management strategies' ('Paths to compliance', p. 629). See also Borzel et al., 'Obstinate and insufficient', p. 1383 and Versluis and Tarr, 'Improving compliance', p. 332.
} 
Table 1. The three theoretical perspectives on compliance.

\begin{tabular}{llc}
\hline $\begin{array}{l}\text { Theoretical } \\
\text { school }\end{array}$ & Reasons for (non-)compliance & Policy interventions \\
\hline Enforcement & $\begin{array}{c}\text { Non-compliance is intentional; states will comply with international } \\
\text { norms, when the benefits of compliance exceed its costs. }\end{array}$ & $\begin{array}{c}\text { Monitoring (transparency) and } \\
\text { sanctioning. }\end{array}$ \\
Management & $\begin{array}{c}\text { Non-compliance is unintentional; states will comply with international } \\
\text { norms, when their obligations are clear and they have the necessary } \\
\text { capacity/resources to do so. }\end{array}$ & $\begin{array}{c}\text { Transparency, capacity } \\
\text { building, and learning. }\end{array}$ \\
Constructivism & $\begin{array}{c}\text { Non-compliance is unintentional, when international norms are } \\
\text { regarded as legitimate. }\end{array}$ & $\begin{array}{c}\text { Social learning and } \\
\text { socialisation. }\end{array}$
\end{tabular}

\subsection{Theorising peer review and its effects}

This section proposes a theoretical framework that details the different processes and mechanisms through which peer reviews are expected to contribute to compliance. The article focuses on three processes in particular: (1) creating transparency; (2) mobilising pressure; and (3) organising learning. Before discussing each of these processes and their corresponding mechanisms, it is important to note that not all of them link neatly to a single theoretical school. Instead, they speak to different theoretical assumptions, and matter for compliance in ways that also go beyond the mechanisms discussed in the compliance literature. Furthermore, the three peer review processes do not work independently of each other but can be mutually reinforcing. Transparency, for example, might not only be relevant in itself, but also be a precondition for processes of peer pressure, public pressure, and learning to take shape.

The first process through which peer reviews can contribute to compliance is by creating transparency of state behaviour. ${ }^{27}$ Monitoring fulfils an important information function. ${ }^{28}$ By periodically reviewing states, peer reviews provide compliance information, facilitate reciprocity, and reassure states that their peers are respecting their commitments as well. This seems particularly pertinent in collective action problems such as the fight against foreign bribery, which gives companies in non-enforcing states a competitive edge over their counterparts in economies that strictly enforce anti-bribery legislation. To break this prisoner-dilemma type situation, ${ }^{29}$ the WGB seeks to create openness of state behaviour towards other states and, as such, raise the costs of shirking. Peer review might also increase the costs of non-compliance by informing domestic audiences about their governments' policy performance, ${ }^{30}$ which, as discussed below, relates to public pressure.

Peer reviews usually cannot sanction states that make insufficient progress or that ignore their recommendations. Instead, they aim to raise compliance activity by praising active enforcers as well as by naming and shaming underperforming states, which can create peer pressure and public

\footnotetext{
${ }^{27}$ Carraro and Jongen, 'Leaving the doors open or keeping them closed'; Thomas Hale, 'Under What Conditions Does International Review Alter National Policy? Refining Concepts and Building Theory', paper presented at the 10th Conference on Political Economy of International Organizations (2017); Kempe R. Hope, 'Toward good governance and sustainable development: The African peer review mechanism', Governance, 18:2 (2005), pp. 283-311; Jongen, 'The authority of peer reviews among states'.

${ }^{28}$ Xinyuan Dai, 'Information systems in treaty regimes', World Politics, 54:4 (2002), pp. 405-36; Robert O. Keohane, After Hegemony: Cooperation and Discord in the World Political Economy (Princeton, NJ: Princeton University Press, 1984); Kenneth A. Oye, 'Explaining cooperation under anarchy: Hypotheses and strategies', World Politics, 38:1 (1985), pp. 1-24.

${ }^{29}$ As to public procurement, all companies and states would benefit if no company bribes the contracting party. This means that all states would have to comply with the OECD Convention. However, insufficient insight into the efforts other states make to detect, expose and prosecute foreign bribery encourages defection.

${ }^{30}$ Xinyuan Dai, 'Why comply? The domestic constituency mechanism', International Organization, 59:2 (2005), pp. 36398; Judith Kelley and Beth A. Simmons, 'Politics by number: Indicators as social pressure in international relations', American Journal of Political Science, 59:1 (2015), pp. 55-70; Judith Kelley, Monitoring Democracy: When International Election Observation Works and Why It Often Fails (Princeton, NJ: Princeton University Press, 2012).
} 
Table 2. The three preview processes and their mechanisms.

\begin{tabular}{lll}
\hline Processes & \multicolumn{1}{c}{ Mechanisms } & Theoretical perspective \\
\hline Transparency & Create insight into states' performance & Enforcement/management \\
Pressure & Generate peer pressure & Enforcement \\
& Mobilise public pressure & \\
Learning and capacitybuilding & $\begin{array}{l}\text { Provide accurate review reports } \\
\text { Stimulate mutual learning }\end{array}$ & Management \\
& Provide technical assistance & \\
& Foster international networks & \\
& Stimulate social learning & Constructivism \\
\hline
\end{tabular}

pressure. ${ }^{31}$ These constitute the second process through which peer reviews are expected to contribute to compliance. Peer pressure might do so by signalling that a country's international standing is at risk. This can create social as well as material costs, as states' inaction might antagonise their strategic partners and harm business relations. Peer reviews can also affect state behaviour in more indirect ways, for example, by informing and mobilising state- and non-state actors that do not participate in the peer review. Specifically, peer reviews provide compliance information to domestic audiences (for example, civil society organisations and the media), who can then hold governments accountable for their actions and exert pressure to comply.

A third way in which peer reviews can promote compliance is by stimulating learning and capacity building among the individuals that participate in the evaluations. ${ }^{32}$ More precisely, peer reviews can clarify international obligations through dialogue and give states insight into their policy shortcomings and blockages. They can additionally provide administrative support, foster international networks, and promote the exchange of best practices among national experts. ${ }^{33}$ Hence, they hold potential to produce effects in states where non-compliance is inadvertent or due to capacity constraints, which speaks to a management approach to compliance. In line with a constructivist perspective, peer reviews might also encourage social learning during plenary sessions and review exercises. Social learning describes a process in which individuals (in this case: participants in a peer review) change their preferences and normative beliefs through social interactions with colleagues from other states. Consequently, state delegates might be persuaded (rather than forced) to comply with the Anti-Bribery Convention. Table 2 connects the different peer review processes, mechanisms and theoretical perspectives, which will be operationalised in section 2 .

\section{Data and methods}

To study the different peer review processes, this article combines data from an online survey, conducted in 2015, and 17 qualitative interviews, conducted between 2014 and 2020. Using

\footnotetext{
${ }^{31}$ On naming and shaming in international organisations, see Jacqueline H. R. Demeritt, 'International organizations and government killing: Does naming and shaming save lives?', International Interactions, $38: 5$ (2012), pp. 597-621; J. C. Sharman, 'The bark is the bite: International organizations and blacklisting', Review of International Political Economy, 16:4 (2009), pp. 573-96; Theresa Squatrito, Magnus Lundgren, and Thomas Sommerer, 'Shaming by international organizations: Mapping condemnatory speech acts across 27 international organizations, 1980-2015', Cooperation and Conflict, 54:3 (2019), pp. 356-77. On naming and shaming in peer reviews, see Carraro, Conzelmann, and Jongen, 'Fears of the peers'; Christoph Meyer, 'The hard side of soft policy coordination in EMU: The impact of peer pressure on publicized opinion in the cases of Germany and Ireland', Journal of European Public Policy, 11:5 (2004), pp. 814-35; De Ruiter, 'Full disclosure?'.

${ }^{32}$ Dunlop and Radaelli, 'Policy learning in the Eurozone crisis'; Dunlop, Radaelli, and Trein (eds), Learning in Public Policy; Hale, 'Under what conditions does international review alter national policy?'; Jongen, 'The authority of peer reviews among states'.

${ }^{33}$ Policy learning does not always yield improved policy outcomes, as states might also emulate erroneous or outdated policies. See J. C. Sharman, 'Dysfunctional policy transfer in national tax blacklists', Governance, 23:4 (2010), pp. 623-39.

${ }^{34}$ While public pressure is expected to change state behaviour by raising the costs of non-compliance, this process takes place outside of the peer review. Thus, a peer review can facilitate or mobilise public pressure (for example, by providing compliance information to domestic advocacy groups) but it cannot exert this pressure itself.
} 
the software program Qualtrics, I sent the survey by email to all but two of the 184 state delegates and ten OECD Secretariat members who were involved in the WGB between January 2014 and June $2015(\mathrm{~N}=192){ }^{35}$ This means that I did a full census (coverage rate of 98.9 per cent). About half of these delegates work for the Ministry of Justice, the Public Prosecution Service, or the Department of the Attorney General. Others work for the Police (including police prosecutors), the Ministry of Economics, Trade and Business, the Ministry of Finance, the Ministry of Foreign Affairs, or dedicated anti-corruption agencies. In these roles, delegates often share responsibility for implementing and enforcing anti-bribery legislation and, consequently, can provide first-hand accounts of the (structural) impediments they experience when doing so. While it is politicians and political leaders that sign up to the Convention, 'ultimately it is law enforcement agencies that implement [it] and take action'. ${ }^{36}$ I therefore did not send the survey to ambassadors and permanent representatives to the OECD in Paris, who are often not substantively involved in the country reviews and are not responsible for implementing and enforcing the Convention. I also did not include actors who are external to the WGB, such as businesses, civil society organisations, and the media. Although they play an extremely important role in the fight against foreign bribery, non-state actors are absent at WGB meetings. ${ }^{37}$

In total, I collected 74 responses (response rate of 38.5 per cent). ${ }^{38}$ The completed sample of respondents reflects the total population of WGB participants in terms of regional background. ${ }^{39}$ When it comes to professional affiliation, eight respondents are OECD staff members and 66 respondents are state delegates. Considering the sample size, the empirical analysis consists of descriptive statistics.

As discussed in section 1, the three processes (transparency, pressure, and learning) do not work independently of each other. Transparency might promote compliance by itself but also facilitate peer pressure, public pressure, and learning. To simplify matters, the empirical analysis operationalised the different peer review processes as shown in Table 3. All processes were studied by means of the survey and interviews. However, social learning proved difficult to study empirically; to conclude that social learning has taken place, individuals' norms need to have discernibly changed during a given timeframe. As a longitudinal analysis is outside of this article's scope, the survey probed into respondents' legitimacy perceptions of the instrument of peer review. Interviews additionally reveal how far personal relations and networks have developed within the WGB, and to what extent delegates share the same values.

The formulation of the different survey items was based on exploratory interviews with participants in anti-corruption peer reviews to ensure that these formulations resonate with language used in peer reviews. The survey was self-administered, fully anonymous, and confidential, which may reduce social desirability bias and promote self-disclosure. ${ }^{40}$ It also did not force respondents to select an answer. When respondents indicated not to know the answer to a specific survey item, I treated this as item non-response.

Pearson product-moment correlations and Cronbach's alpha were used to study the relationship between these survey items. ${ }^{41}$ While the WGB's perceived capacity to generate peer pressure

\footnotetext{
${ }^{35}$ Two email addresses bounced.

${ }^{36}$ Interview 14.

${ }^{37}$ The OECD does hold annual consultations with business, trade unions, and civil society, and meets with them during country visits.

${ }^{38}$ Two reminder emails were sent.

${ }^{39}$ Thirty-nine responses from the Western Europe and Others Group of States, 15 responses from African, American, and Asian states, and 13 responses from Central and Eastern Europe. Seven respondents did not disclose their regional background. Western Europe and Others refers to the UN classification and includes Western Europe, Australia, Canada, Israel, New Zealand, Turkey and the United States.

${ }^{40}$ Edith de Leeuw and Nejc Berzelak, 'Survey mode or survey modes?', in Christof Wolf, Dominique Joye, Tom Smith, and Yang-Chih Fu (eds), The SAGE Handbook of Survey Methodology (London: Sage Publications, 2016), pp. 142-56.

${ }^{41}$ See the appendix.
} 
Table 3. Operationalisation and survey items.

\begin{tabular}{|c|c|c|c|}
\hline \multicolumn{2}{|c|}{ Peer review processes } & \multirow{2}{*}{$\begin{array}{l}\text { Survey items } \\
\text { To what extent do you agree or disagree with } \\
\text { this statement: 'In the absence of the OECD } \\
\text { WGB, it would be difficult to acquire } \\
\text { information about the policy practices of } \\
\text { other member states in this field'? }\end{array}$} & \multirow{2}{*}{$\begin{array}{c}\text { Answers } \\
\begin{array}{c}1=\text { strongly disagree, } \\
2=\text { disagree }, 3=\text { agree } \\
4=\text { strongly agree. }\end{array}\end{array}$} \\
\hline Transparency & & & \\
\hline \multirow[t]{3}{*}{ Pressure } & Peer pressure & $\begin{array}{l}\text { Generally speaking, to what extent do you } \\
\text { believe that the OECD WGB successfully exerts } \\
\text { state-to-state (peer) pressure? }\end{array}$ & $\begin{array}{l}1=\text { not at all, } 2=\text { to some } \\
\text { extent, } 3=\text { to a large extent, } \\
4=\text { completely. }\end{array}$ \\
\hline & Public pressure & $\begin{array}{l}\text { Generally speaking, to what extent do you } \\
\text { believe that the OECD WGB successfully exerts } \\
\text { public pressure? }\end{array}$ & $\begin{array}{l}1=\text { not at all, } 2=\text { to some } \\
\text { extent, } 3=\text { to a large extent, } \\
4=\text { completely. }\end{array}$ \\
\hline & $\begin{array}{l}\text { Pressure at the } \\
\text { individual level }\end{array}$ & $\begin{array}{l}\text { To what extent do you agree or disagree with the } \\
\text { following statement: 'I feel under pressure } \\
\text { from the OECD WGB to implement review } \\
\text { recommendations'? }\end{array}$ & $\begin{array}{l}1=\text { strongly disagree, } \\
2=\text { disagree, } 3=\text { agree, } \\
4=\text { strongly agree. }\end{array}$ \\
\hline \multirow[t]{5}{*}{$\begin{array}{l}\text { Learning and } \\
\text { capacity } \\
\text { building }\end{array}$} & Accuracy of reports & $\begin{array}{l}\text { Generally speaking, to what extent do you } \\
\text { believe that the OECD WGB provides an } \\
\text { accurate overview of reviewed states' } \\
\text { performance? }\end{array}$ & $\begin{array}{l}1=\text { not at all, } 2=\text { to some } \\
\text { extent, } 3=\text { to a large extent, } \\
4=\text { completely. }\end{array}$ \\
\hline & Mutual learning & $\begin{array}{l}\text { Generally speaking, to what extent do you } \\
\text { believe that the OECD WGB triggers mutual } \\
\text { learning? }\end{array}$ & $\begin{array}{l}1=\text { not at all, } 2=\text { to some } \\
\text { extent, } 3=\text { to a large extent, } \\
4=\text { completely. }\end{array}$ \\
\hline & Technical assistance & $\begin{array}{l}\text { Generally speaking, to what extent do you } \\
\text { believe that the OECD WGB provides } \\
\text { (technical) assistance to states to implement } \\
\text { the OECD Anti-Bribery Convention? }\end{array}$ & $\begin{array}{l}1=\text { not at all, } 2=\text { to some } \\
\text { extent, } 3=\text { to a large extent, } \\
4=\text { completely. }\end{array}$ \\
\hline & $\begin{array}{l}\text { International } \\
\text { cooperation }\end{array}$ & $\begin{array}{l}\text { Generally speaking, to what extent do you } \\
\text { believe that the OECD WGB facilitates } \\
\text { international cooperation? }\end{array}$ & $\begin{array}{l}1=\text { not at all, } 2=\text { to some } \\
\text { extent, } 3=\text { to a large extent, } \\
4=\text { completely. }\end{array}$ \\
\hline & $\begin{array}{l}\text { Social learning } \\
\text { (legitimacy } \\
\text { perceptions). }\end{array}$ & $\begin{array}{l}\text { How appropriate or inappropriate do you find it } \\
\text { that a peer review is used to assess states' } \\
\text { performance in the field of corruption? }\end{array}$ & $\begin{array}{l}1 \text { = very inappropriate, } \\
2=\text { inappropriate, } \\
3=\text { appropriate, } 4=\text { very } \\
\text { appropriate. }\end{array}$ \\
\hline
\end{tabular}

correlates with its capacity to exert public pressure $(\mathrm{r}=.0 .432 ; \mathrm{p}<0.001)$, their internal consistency is too low to merge the two items (Cronbach's alpha of 0.599 ). In addition, most dimensions of learning and capacity building (accurate reports, ${ }^{42}$ mutual learning, technical assistance, and international cooperation) significantly correlate (Cronbach's alpha of 0.693).

Next to the survey, 17 qualitative interviews were conducted. These interviews help to contextualise the survey findings and to explore to what extent respondents consider these processes relevant for promoting compliance. Two interviews were conducted with staff members of the OECD Anti-Corruption Division and 15 with state delegates (see Appendix). The interviews, which lasted between thirty and ninety minutes, were done in person or by phone, Skype, and Zoom. Interviewed delegates come from different world regions in proportions that largely reflect the total population of participants in the WGB. The study includes interviewees from countries with different levels of enforcement of the Convention as well as long-term members and relative newcomers to the WGB.

This article studies how far peer review is perceived to create transparency, to exert pressure, and to stimulate learning, and how far these processes are regarded as relevant for promoting compliance. This focus on perceptions offers several advantages compared to an external assessment of these processes. As discussed in section 1, it is extremely difficult to establish a causal

\footnotetext{
${ }^{42}$ Theoretically, perceptions of the accuracy of reports fit with both transparency and policy learning. As I found significant correlations between perceptions of accurate reports and various subdimensions of policy learning, but not between perceptions of accurate reports and transparency, I treat this as a subdimension of learning.
} 
connection between a peer review and state compliance. An analysis of perceptions helps to unpack the (perceived) relevance of different processes in promoting compliance, by identifying how these processes take shape, how state delegates experience them, and how far they help (or do not help) delegates in overcoming barriers to compliance. That said, this article can make no claims about causal relations. Where possible, however, accounts from interviewees were verified against information from country evaluation reports and public statements.

\section{Peer review in the WGB}

The WGB is responsible for reviewing state compliance with the 1997 OECD Convention on Combating Bribery of Foreign Public Officials in International Business Transactions and the 2009 Anti-Bribery Recommendation to further combat foreign bribery. The origins of this agreement can be traced to the neoliberal agenda promoted in the early 1990s, which identified the detrimental consequences of foreign bribery for free trade. ${ }^{43}$ While United States (US) companies had been facing restrictions on foreign bribery since the enactment of the Foreign Corrupt Practices Act in 1977, many European countries not only condoned foreign bribery, but even encouraged it through tax benefits. After years of US lobbying, the Anti-Bribery Convention became the first multilateral agreement to level the playing field in international business transactions by criminalising the supply side of bribery.

The WGB has a dual focus on generating pressure and facilitating mutual learning. As stated on its website, the group aims 'to improve the capacity of Parties to fight bribery in international business transactions by examining their undertakings in this field through a dynamic process of mutual evaluation and peer pressure'. ${ }^{44}$ It additionally serves an 'educational function as participants discuss problems and different approaches'. ${ }^{45}$ Over the past decades, the WGB has grown from 34 to 44 states, which include all 37 OECD members, Argentina, Brazil, Bulgaria, Costa Rica, Peru, Russia, and South Africa. The group meets four times a year at the OECD headquarters in Paris to discuss country evaluations and to exchange experiences on how to enforce the Anti-Bribery Convention. Meetings are held in a closed setting in the expectation that delegates will express their views openly. ${ }^{46}$

There are four phases of peer review within the WGB. These each address a particular stage of compliance with the Convention and progressively place more stringent demands on member states. The main objective of Phase 1 is to evaluate the adequacy of national legislation to implement the Convention. This phase comprises both self- and peer assessments in the form of questionnaires, but does not include an onsite visit by the reviewing team. Phase 2 deals with the actual implementation of the Convention. It includes an evaluation questionnaire and an onsite visit of about a week, undertaken by experts from two countries who act as lead examiners, supported by the OECD secretariat. Phase 3 is the first in a series of follow-up phases to the evaluations carried out under Phase 2 and focuses on countries' enforcement of the Convention. It reviews whether states conduct investigations into bribery cases and penalise financial malfeasance abroad. Phase 3 includes onsite visits and questionnaires, but is more focused and shorter

\footnotetext{
${ }^{43}$ For an overview of the history of the Convention, see Kenneth Abbott and Duncan Snidal, 'Values and interests: International legalization in the fight against corruption', The Journal of Legal Studies, 31:S1 (2002), pp. S141-S177; Jakobi, 'The OECD and crime'; Jennifer McCoy and Heather Heckel, 'The emergence of a global anti-corruption norm', International Politics, 38:1 (2001), pp. 65-90.

${ }^{44}$ http://www.oecd.org/daf/anti-bribery/anti-briberyconvention/phase3countrymonitoringoftheoecdanti-briberyconvention.htm\} accessed 30 November 2020.

${ }^{45}$ \{http://www.oecd.org/investment/anti-bribery/anti-briberyconvention/phase2countrymonitoringoftheoecdanti-briberyconvention.htm $\}$ accessed 30 November 2020.

${ }^{46}$ Bonucci, 'Article 12'.
} 
than Phase 2. Phase 4 was launched in 2016. It continues its focus on domestic enforcement but additionally reviews several cross-cutting and country-specific issues. ${ }^{47}$

Each evaluation ends with the adoption of a country report with recommendations for improvement, which is published on the OECD website. One strength of the WGB is that the state under review cannot block the adoption of the report or its recommendations. In addition, the WGB takes a graduated approach to reviewing state compliance; states cannot proceed to the next review phase unless they have adequately implemented the recommendations from previous rounds. Should their performance be deemed unsatisfactory, the WGB might demand that they do the evaluation for a second time (that is, a -bis evaluation) or even a third time (-ter evaluation).

When it comes to compliance with the Anti-Bribery Convention, results are mixed. Although 44 countries, which together account for more than 66 per cent of world exports, have signed and implemented the Convention, only a handful enforce the Convention domestically. An OECD publication concludes that 21 out of 44 States Parties have never concluded a foreign bribery case. ${ }^{48}$ Many states still show inadequacies in their legal frameworks. Progress reports by Transparency International additionally reveal that enforcement of the Convention is erratic; between 2018 and 2020, the number of states that were actively enforcing the Convention declined from seven to four. ${ }^{49}$ At the same time, six countries have beefed up their efforts since 2018. While several interviewed delegates admitted that more could be done to prosecute and sanction foreign bribery offences, many of them pointed to discernible results both in their own countries and other WGB states. ${ }^{50}$ Examples include legislative changes (for example, in relation to criminal liability of legal persons), legal proceedings against multinationals, and public reopening of investigations.

\section{Transparency, pressure, and learning in the WGB}

\subsection{Transparency}

To what extent is the WGB effective in organising transparency, pressure, and learning? When it comes to creating transparency, the survey indicates that a large majority of respondents agree (50.7 per cent) or even strongly agree (33.3 per cent) that in the absence of the WGB it would be difficult to acquire information about the steps that other countries have taken to fight foreign bribery (Figure 1). ${ }^{51}$ Considering that most states do not make a lot of data on enforcement publicly available, the WGB functions as an important platform to exchange information. In the evaluations, the WGB specifically requests states to provide information on (ongoing) investigations and prosecutions of foreign bribery, which are subsequently circulated within the Group. ${ }^{52}$ Important information is additionally shared during the roundtable discussion, the so-called Tour de Table, at the start of each WGB meeting. ${ }^{53}$

\footnotetext{
${ }^{47}$ More information on the review phases is available at: $\{\mathrm{http}: / /$ www.oecd.org/daf/anti-bribery/countrymonitoringoftheoecdanti-briberyconvention.htm\} accessed 30 November 2020.

${ }^{48}$ OECD, 'Fighting the crime of foreign bribery: The Anti-Bribery Convention and the OECD Working Group on Bribery', available at: \{http://www.oecd.org/daf/anti-bribery/Fighting-the-crime-of-foreign-bribery.pdf $\}$ accessed 30 November 2020.

${ }^{49}$ Gillian Dell, 'Exporting Corruption: Progress Report 2020: Assessing Enforcement of the OECD Anti-Bribery Convention', available at: \{https://images.transparencycdn.org/images/2020_Report_ExportingCorruption_English.pdf\} accessed 13 October 2020.

${ }^{50}$ Interviews $1,3,4,7,8,13,14,15$.

${ }^{51}$ On a 1-4 scale, Mean of 3.16 (standard deviation (SD) of 0.72), 95 per cent confidence interval (CI) [2.99-3.33].

${ }^{52}$ Since 2010, the OECD has published enforcement data on an annual basis. The questionnaires used in Phase 3 and 4 request states to provide data on domestic enforcement.

${ }^{53}$ Interviews $8,13,15$; another delegate mentioned that you can get a very good insight into states' enforcement actions by attending plenary sessions (interview 16).
} 
60

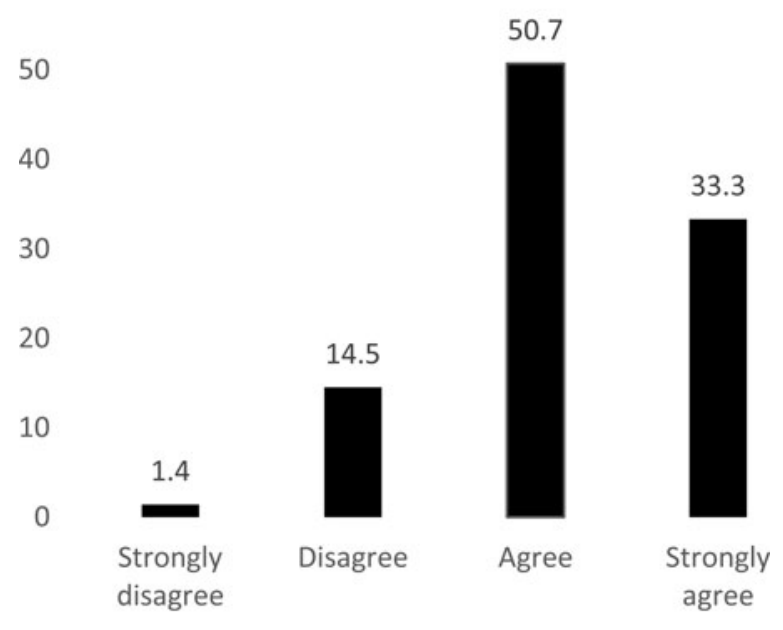

Figure 1. Perceptions of transparency in percentages.

Transparency

\section{Survey question:}

- To what extent do you agree or disagree with this statement: 'In the absence of the OECD WGB, it would be difficult to acquire information about the policy practices of other member states in this field'? $(\mathrm{N}=69)$.

\subsection{Pressure}

The second way in which the WGB can promote compliance is by mobilising pressure on states, which can take the form of state-to-state pressure or pressure from the public. Figure 2 shows that more than three-quarters of respondents (76.1 per cent) perceive that the WGB exerts peer pressure to a large extent or completely. ${ }^{54}$ At 51.4 per cent, this percentage is significantly lower when it comes to the WGB's capacity to mobilise public pressure. ${ }^{55}$

Delegates exert peer pressure by exposing, questioning, and shaming recusant states, holding each other accountable for their performance. ${ }^{56}$ Crucially, monitoring is not a one-off exercise that allows states to regress as soon as the review is over. Rather, states have to regularly report on legislative changes and investigations, even when they are not currently under review. ${ }^{57}$ Delegates then have ample opportunity to ask each other critical questions; for instance, about why they have not acted on specific foreign bribery allegations, or have not responded to requests for mutual legal assistance. In case of persistent gaps in implementation and compliance, the WGB may request states to do a repeat evaluation or suspend them from advancing to the next review phase. Because of the peer review's ability to take more stringent measures over time, pressure in the WGB 'builds up over different plenaries. Sometimes, ... over years, even. ${ }^{58}$ Various interview accounts suggest that peer pressure also works indirectly through states' self-perceived identity and reputation, and does not always need to take the form of naming and shaming. ${ }^{59}$ As one delegate remarked: 'from a country perspective, we don't want to be seen inferior or less effective than [member state X]'. ${ }^{60}$

\footnotetext{
${ }^{54}$ Mean of 2.92 (SD 0.67), 95 per cent CI [2.76-3.07].

${ }^{55}$ Mean of 2.61 (SD 0.79), 95 per cent CI [2.43-2.80]. Paired-samples t-tests reveal that this difference is significant $\mathrm{t}=3.056, \mathrm{p}<0.01$.

${ }^{56}$ Interviews 1, 2, 9.

${ }^{57}$ Interviews 1, 4, 5, 13, 17.

${ }^{58}$ Interview 16.

${ }^{59}$ Interviews 9, 14, 17.

${ }^{60}$ Interview 14.
} 
If pressure behind closed doors does not suffice, the WGB may threaten to take additional exhortative measures. ${ }^{61}$ To mobilise public pressure, for instance, the WGB can contact the minister of the respective country or dispatch a technical or high-level mission. ${ }^{62}$ In recent years, such missions have been sent to Argentina, Brazil, Japan, Russia, and Sweden. Further, to shape public opinion and create domestic awareness, the WGB also does not shy away from publishing critical press statements, which are often translated in the reviewed state's local language. ${ }^{63}$ Such statements make the evaluation reports available to the public at large, and are regularly picked up by civil society and the media. ${ }^{64}$ Concerned about their reputation and image, delegates try to fend off criticism ${ }^{65}$ and influence the final wording of these communications. ${ }^{66}$ As one of them remarked: 'Sometimes, we spend more time on negotiating the language of the press reports than on the [evaluation] reports themselves. ${ }^{67}$

Even though peer pressure is formally targeted at states and not at individual delegates, the latter often feel the pressure personally. ${ }^{68}$ A large majority of surveyed delegates agree (72.1 per cent) or even strongly agree (18 per cent) that they feel under pressure from the WGB to act upon the recommendations they have received (Figure 2). ${ }^{69}$ In the interviews, several delegates indicated to feel nervous about their country review or having their reports discussed in plenary, ${ }^{70}$ and spoke about the social discomfort they felt when being subjected to review. The atmosphere at these meetings was then also described as 'tense, ${ }^{71}$ at times with a lot of 'emotion in the room'.72

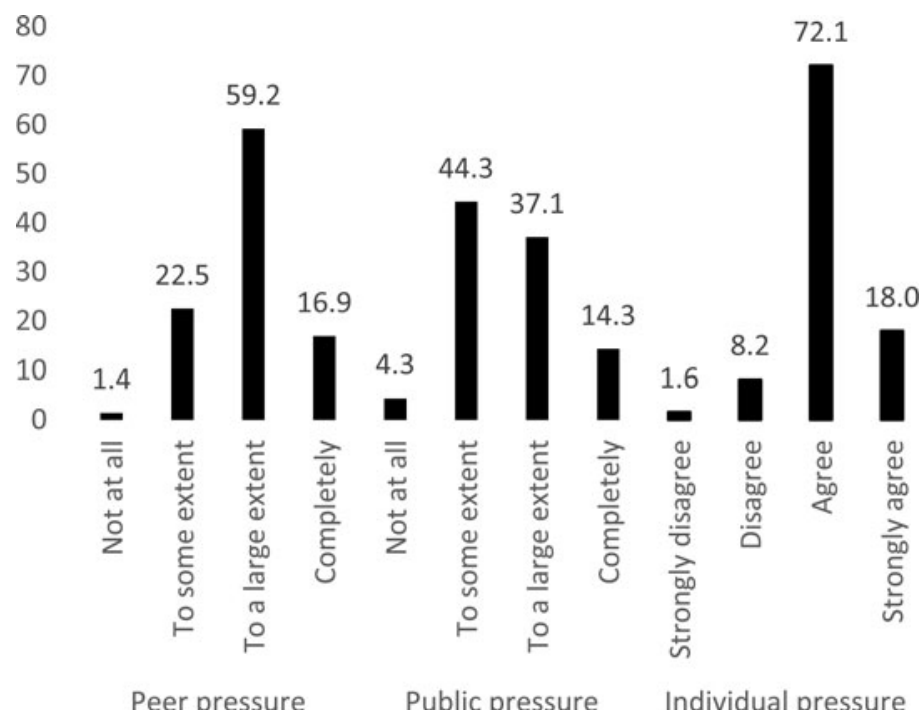

Figure 2. Perceptions of pressure, in percentages.

\footnotetext{
${ }^{61}$ For an overview, see: \{https://www.oecd.org/corruption/countrymonitoringoftheoecdanti-briberyconvention.htm\} accessed 13 October 2020.

${ }^{62}$ Interviews 2, 7, 10, 11, 12, 13, 16.

${ }^{63}$ Interview 2.

${ }^{64}$ Interviews $1,4,5,8,9,11,12$.

${ }^{65}$ Interviews $15,16$.

${ }^{66}$ Interviews 8, 13; delegates also seek to affect the final wording of evaluation reports; interviews 2, 3, $13,14$.

${ }^{67}$ Interview 13; also 8.

${ }^{68}$ Interviews 7, 9; Likewise, interview 16 states that: 'the delegates of those countries feel that pressure probably also personally ... the pressure is not meant [to be] personal, but people perceive it as such'.

${ }^{69}$ Mean of 3.07 (SD 0.57), 95 per cent CI [2.92 - 3.21]. We did not ask OECD Secretariat members this question.

${ }^{70}$ Interviews 3, 9.

${ }^{71}$ Interviews 3, 6, 7, 14.

${ }^{72}$ Interview 8
} 
Referring to the discussions on their country's performance, one delegate explained: 'There is challenge and there is critique and there is quite a lot of aggression. My personal view is that it got slightly out of hand ... but it was a key part of the dynamics. Sociologically that worked. ${ }^{, 73}$

\section{Survey questions:}

- Generally speaking, to what extent do you believe that the OECD WGB:

- exerts state-to-state (peer) pressure? $(\mathrm{N}=71)$

- exerts public pressure? $(\mathrm{N}=70)$

- To what extent do you agree or disagree with the following statement: 'I feel under pressure from the OECD WGB to implement review recommendations'? $(\mathrm{N}=61)$

\subsection{Learning and capacity building}

What sets peer reviews apart from traditional monitoring bodies is their focus on policy learning, capacity building, and international networking. This taps into four aspects: the extent to which the WGB: (1) provides an accurate overview of reviewed states' performance; (2) promotes mutual learning; (3) provides (technical) assistance; and (4) facilitates international cooperation.

In total, 48.6 per cent of survey respondents claim that the WGB delivers an accurate overview of the reviewed state's performance to a large extent, and 23.6 per cent hold that the WGB does so completely (Figure 3). ${ }^{74}$ Many interviewed delegates are of the opinion that the WGB provides a comprehensive, detailed assessment of states' performance. ${ }^{75}$ The fact that evaluation reports draw upon a variety of sources, collected from both state and non-state actors, positively shapes delegates' perceptions of the accuracy of reports. ${ }^{76}$ In addition, peer review reports go through various rounds of discussion, which allows all of the involved actors to share their views. ${ }^{77}$ Finally, the OECD Secretariat was often lauded for providing additional information in the reviews, thereby contributing to the quality and consistency of evaluation reports. ${ }^{78}$ There is, however, no reason for complacency yet; 27.8 per cent of respondents indicate that the WGB provides an accurate assessment of states' performance only to a limited extent.

The findings additionally indicate that the WGB is rather effective in promoting mutual learning and international cooperation. Just under 70 per cent of respondents report that the WGB is to a large extent or even completely able to facilitate these processes. ${ }^{79}$ Perceptions of the WGB's capacity to provide (technical) assistance to states are, however, significantly lower. ${ }^{80}$ Interviewees discussed different stages of the review process at which these processes occur: Participation in plenary discussions and in the evaluation exercises offer important opportunities for learning, exchange of best practices, and networking. ${ }^{81}$ Countries give presentations ${ }^{82}$ and share insights into how they have dealt with intricate bribery cases. ${ }^{83}$ In their informal biannual meetings,

\footnotetext{
${ }^{73}$ Interview 8; similar dynamics were reported in interviews 3, 6.

${ }^{74}$ Mean of 2.96 (SD 0.72), 95 per cent CI [2.79-3.13].

${ }^{75}$ Interviews $1,2,3,10,13,17$.

${ }^{76}$ Interview 1, 3, 4

${ }^{77}$ Interview 2, 10, 11. Interestingly, peer reviews that allow for comparably less interactive discussion, such as the World Trade Organisation's Trade Policy Review Mechanism, produce less critical evaluations and more tangential statements by member states; see Karlas and Parízek, 'The process performance of the WTO Trade Policy Review Mechanism'.

${ }^{78}$ Interviews 2, 8, 11, 17; interviews 9 and 14 also discuss the importance of the OECD Secretariat for the quality, consistency and effectiveness of the review exercises.

${ }^{79}$ Mean of 2.94 (SD 0.80), 95 per cent CI [2.76 - 3.13] and $2.91(0.81), 95$ per cent CI [2.72-3.11], respectively.

${ }^{80}$ Mean of 2.44 (SD 0.77), 95 per cent CI [2.26-2.63]. Paired-samples t-tests reveal significant differences between perceptions of technical assistance and mutual learning $(\mathrm{t}=4.634 ; \mathrm{p}<0.000)$, and between perceptions of technical assistance and international cooperation $(\mathrm{t}=4.670 ; \mathrm{p}<0.000)$.

${ }^{81}$ Interviews 2, 4, 10, 15.

${ }^{82}$ Interview 16.

${ }^{83}$ Interview 12.
} 
law enforcement officials additionally exchange experiences on how to enforce anti-bribery legislation domestically. This helps to build capacity and to form networks to investigate foreign bribery cases. ${ }^{84}$ Finally, the mere practice of bringing together different departments to fill out a self-assessment questionnaire offers a key learning moment, and helps to raise awareness domestically about the need to prosecute foreign bribery. ${ }^{85}$ This is important, as effective implementation and enforcement requires action from a variety of state actors (for example, different law enforcement agencies and ministries), some of which are less cognisant of the WGB and its work.

Next to policy learning, interviews provide some evidence of social learning. Already in the early 2000s, Kenneth Abbott and Duncan Snidal described the prosecutors in the WGB as a 'nascent epistemic community', ${ }^{86}$ an international network of professionals that share similar values regarding foreign bribery. Almost twenty years later, this description still holds. Meeting every three months for a week, delegates develop close networks and personal relationships, building mutual trust and understanding. ${ }^{87}$ Through these interactions, values and expectations converge about appropriate behaviour not only in the context of peer reviewing, ${ }^{88}$ but also in relation to providing mutual legal assistance and information in transnational bribery investigations. ${ }^{89}$ Delegates that do not conform to these expectations risk being shunned or 'mildly ostracised' ${ }^{90}$ In one reported instance, recalcitrant delegates from an (at the time) new member state were simply told that 'this is not how we do things here'. ${ }^{91}$ The survey additionally indicates that peer review is widely accepted as a monitoring instrument in the anti-corruption regime: 45.9 per cent of respondents consider its use appropriate and 51.4 per cent even very appropriate. ${ }^{92}$ While this does not confirm that social learning has

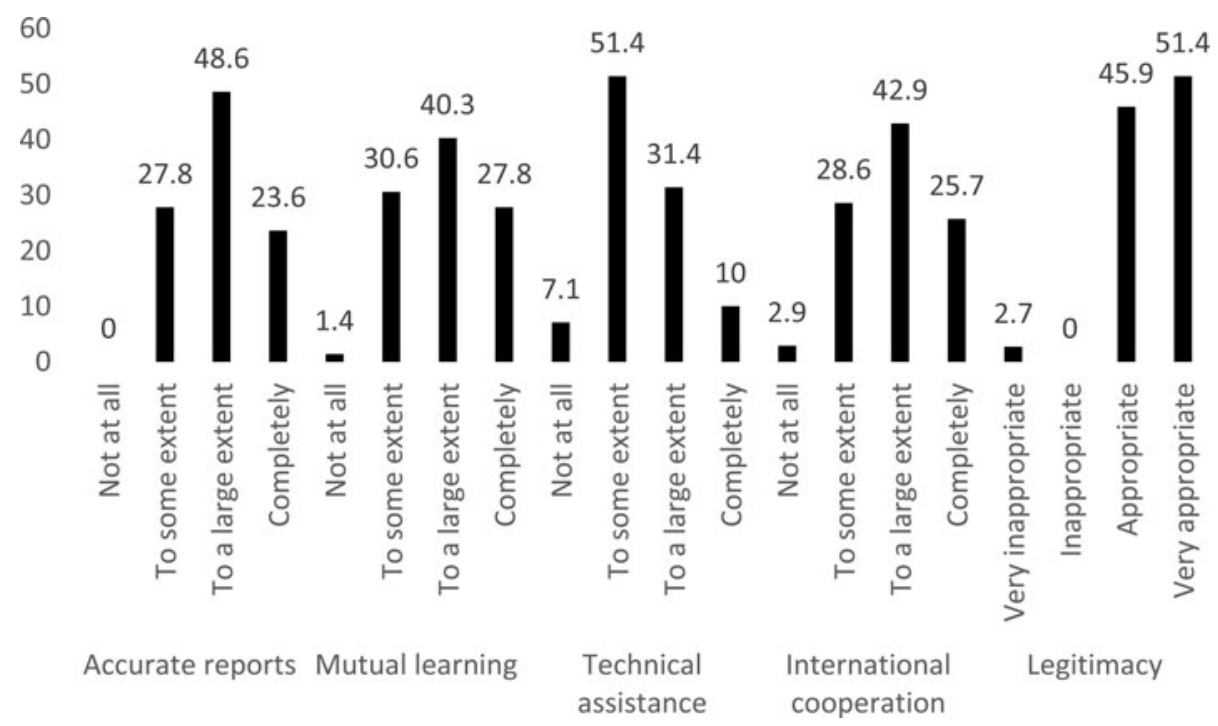

Figure 3. Perceptions of learning and capacity building, in percentages.

\footnotetext{
${ }^{84}$ Interviews 13, 14, 17.

${ }^{85}$ Interview 11.

${ }^{86}$ Abbott and Snidal, 'Values and interests', p. 166.

${ }^{87}$ Interviews 2, 4, 16.

${ }^{88}$ Interviews 1, 2.

${ }^{89}$ Interviews $1,4,8$.

${ }^{90}$ Interview 8; comparable dynamics were reported in interviews 2, 9.

${ }^{91}$ Interview 1.

${ }^{92}$ Mean of 3.46 (SD 0.65), 95 per cent CI [3.31-3.61].
} 
taken place - participants might have already held these views before they joined the WGB - it does show that peer review is now widely perceived as a legitimate policy tool.

\section{Survey questions:}

- Generally speaking, to what extent do you believe that the OECD WGB:

- presents an accurate overview of reviewed states' performance ? $(\mathrm{N}=72)$

- triggers mutual learning? $(\mathrm{N}=72)$

- provides (technical) assistance to states to implement the OECD Anti-Bribery Convention? $(\mathrm{N}=70)$

- facilitates international cooperation? $(\mathrm{N}=70)$

- How appropriate or inappropriate do you find it that peer review is used to assess states' performance in the field of corruption? $(\mathrm{N}=74)$

\section{Peer review and compliance with the Anti-Bribery Convention}

The previous section concluded that peer review in the WGB is perceived as quite successful in creating transparency, organising pressure, and stimulating learning and international cooperation. And yet, as shown in section 3, compliance levels are mixed and erratic. Drawing upon interviews, this section explores to what extent these processes are perceived to contribute to compliance.

\subsection{Transparency}

To what extent is transparency considered relevant for promoting compliance? The preceding analysis showed that the WGB fulfils a pivotal role in providing states with information about their peers' performance. Even though in many states the number of prosecutions is still too low to be considered (fully) compliant, some countries are making great strides to comply with the Convention. Delegates from other states notice and recognise these efforts. ${ }^{93}$

As already anticipated in section 1, it is extremely difficult to isolate the (perceived) impact of transparency on compliance levels from other peer review processes, such as peer pressure and public pressure. For peer pressure to take shape (both through institutionalised channels and more informally), insight into other states' performance appears to be crucial. ${ }^{94}$ Likewise, public pressure can only materialise when a peer review creates transparency about states' performance vis-à-vis domestic audiences. Thus, transparency can be best conceived of as a precondition for these other processes to take shape, which, in turn, might boost compliance levels.

\subsection{Pressure}

To what extent are processes of peer pressure and public pressure regarded as relevant for promoting compliance? Starting with peer pressure: peer review in the WGB was expected to contribute to compliance by signalling that states' international standing and reputation are at risk, creating social and material costs. States that do not fulfil their obligations under the Convention or are uncooperative in transnational bribery investigations might risk alienating their strategic partners. As one delegate explained: 'They are your economic partners who sit there, so it is quite unpleasant if you end up in an argument .... It is not just reputation, but just ... you will be perceived as some sort of banana republic. ${ }^{, 95}$ Recalcitrant behaviour is perceived to make it less likely that other states will respond positively to requests for mutual legal assistance, ${ }^{96}$

\footnotetext{
${ }^{93}$ Interviews 2, 3, 8, 14 .

${ }^{94}$ See also Carraro and Jongen, 'Leaving the doors open or keeping them closed?'.

${ }^{95}$ Interview 1.

${ }^{96}$ Interview 1.
} 
and might affect diplomatic relations with other states. ${ }^{97}$ This corresponds to research by Rochelle Terman and Erik Voeten, who find that strategic partners are less likely to criticise each other in a peer review but, when they do so, are more receptive to this criticism. ${ }^{98}$

Peer pressure was, however, most frequently discussed in relation to the threat of having to repeat an evaluation round (that is, the -bis or -ter evaluations) ${ }^{99}$ or that other measures, more visible to domestic audiences, will be taken. Repeat evaluations are time-consuming, burdensome, and distract a large number of officials across departments and ministries from their day-to-day activities. ${ }^{100}$ As one delegate remarked: A -bis evaluation would be 'the very worst of the bad things that could happen to us. ${ }^{101}$ In several reported instances, just the threat that such measures might be taken has motivated states to make at least minimal (albeit not always sufficient) efforts to comply. ${ }^{102}$

Yet, the ability of a peer review to produce reform through peer pressure should not be overstated. As shown in section 4, while delegates often personally feel under pressure to implement reforms, their colleagues who work for other departments or ministries (and who do not participate in the WGB) at times feel less bound by the compromises that have been reached in the OECD. ${ }^{103}$ One delegate explained how some ministries are more cooperative in the evaluations than others: The Ministry of Justice might be helping, 'because they have to sit at those meetings. ... But then [the Ministry of] Finance is much more distanced from this. Or the ... Association of Accountants, they may have heard from this once, but try to make them feel the pressure. That is difficult. ${ }^{104}$ Peer review might raise the material and social costs of non-compliance for delegates who do not want to return to the next WGB meeting empty-handed. This peer pressure, however, does not necessarily transpire to other departments, ministries, or the government. ${ }^{105}$

Considering that peer pressure does not always trickle down to all responsible actors, public pressure holds more potential to generate reform, as the material and social costs of noncompliance fall upon governments rather than individual delegates. Interviews indicate that many (although certainly not all) states do care about their reputation, ${ }^{106}$ and that delegates try their best to avoid negative publicity. ${ }^{107}$ Several delegates discussed how non-compliance might damage the reputation of a country's business climate and foreign investments. ${ }^{108}$ In the past, the WGB has threatened to blacklist UK companies for the country's lack of compliance with the Convention, ${ }^{109}$ which resulted in a complete overhaul in legislation and the adoption of the UK Bribery Act. ${ }^{110}$ Furthermore, in several instances, the high-level missions that have been

\footnotetext{
${ }^{97}$ Interview 8; This also works the other way around: delegates from countries with strong economic, historic or political ties, at times try to assuage the recommendations their strategic partners receive; interviews 2, 8, 9, $10,12$.

${ }^{98}$ Terman and Voeten, 'The relational politics of shame'.

${ }^{99}$ Interviews $1,3,4,8$.

${ }^{100}$ Interviews 3, 8; the financial and administrative costs of having to repeat an evaluation round are also discussed in interviews 1,4 .

${ }^{101}$ Interview 9.

${ }^{102}$ Interviews 1, 3, 9; interview 3, for example, explained how the Public Prosecution Service stepped up their game to be able to present positive results in the WGB, not only to avoid reputational damage but also to make sure they did not have to repeat an evaluation round.

${ }^{103}$ Interviews $1,2,7,8,9$.

${ }^{104}$ Interview 2, also 1. Another delegate discussed similar dynamics, but mentioned that this might be due to lower awareness of the WGB rather than active resistance (interview 17).

${ }^{105}$ The WGB is currently discussing options to take additional measures, which would further raise the material costs of non-compliance (interview 13).

${ }^{106}$ Interviews $3,4,15$.

${ }^{107}$ Interviews $2,3,13,14$.

${ }^{108}$ Interviews $1,3,8,12,13,17$; compliance signals that a state's companies can be trusted and that it is safe to invest in them; interview 14 .

${ }^{109}$ James Boxell and Elizabeth Rigbey, 'Exports warning as bribery law is delayed', Financial Times (31 January 2011).

${ }^{110}$ Cecily Rose, International Anti-Corruption Norms: Their Creation and Influence on Domestic Legal Systems (Oxford: Oxford University Press, 2015). Today the UK scores consistently high in rankings of state enforcement of the Anti-Bribery Convention.
} 
dispatched to states, and in which WGB representatives meet with ministers and other senior officials, are claimed to have set things in motion and to have raised awareness of foreign bribery. ${ }^{111}$

While the threat of public shaming may have motivated some change domestically, the impact of public pressure is limited by the perception still present in some WGB states that foreign bribery does not directly affect the public, ${ }^{112}$ or that corruption is not a large problem to begin with. ${ }^{113}$ In many states, the focus of the public, the media, and politicians on this crime is low. As one delegate explained: 'we informed the government that we had received a negative evaluation report. ... It hardly caused a stir, which makes things even more difficult for me, trying to [get people to] implement these recommendations. ${ }^{\text {,14 }}$

External factors, however, such as the exposure of a corruption scandal can have a profound impact on the WGB's capacity to mobilise peer and public pressure, and promote compliance. ${ }^{115}$ Well-known examples are the abovementioned UK Bribery Act, which was adopted after a bribery scandal, and Germany's increased enforcement activity after a corruption scandal that involved electronics giant Siemens. Suddenly falling under increased pressure and scrutiny from domestic advocacy groups, the media, and the WGB, states become incentivised to take action against foreign bribery. In addition, governments become more susceptible to adverse publicity on their anti-corruption strategies and more receptive to new policy ideas. As one delegate contended: all we have to do '[is to] hope for a large foreign bribery scandal. Then you will see how fast [governments] will [implement change]. ${ }^{, 16}$ One strength of peer reviews is that, when a scandal is exposed, they have already identified the legislative shortcomings that need to be addressed, offering tailor-made solutions that can be readily implemented. Delegates discussed how the WGB helps to legitimise reform domestically and empowers reform-oriented actors vis-à-vis less supportive government departments and the private sector. ${ }^{117}$ They often refer to the OECD reports and recommendations to promote and justify policy reform at home. ${ }^{118}$ In line with observations by Tony Porter and Michael Webb on other OECD peer reviews, 'national officials can use the support of their peers in other states to try to sway public opinion in their bureaucratic battles'. ${ }^{119}$

\subsection{Learning and capacity building}

Finally, to what extent are learning, capacity building, and international networks considered relevant for promoting compliance? Section 4 showed that delegates learn from their participation in the WGB, and obtain new insights and skills on how to investigate and sanction foreign bribery. This might be particularly pertinent for experts from new member states who may have never investigated or prosecuted foreign bribery before. ${ }^{120}$ The WGB additionally creates awareness among law enforcement officials to prosecute this crime, and fosters networks among them that are pivotal for conducting transnational investigations. Within these networks, norms and expectations converge about appropriate behaviour, providing some evidence of social learning.

\footnotetext{
${ }^{111}$ Interviews $15,17$.

${ }^{112}$ Interviews 2, 8, 9, 10, 11, 12.

${ }^{113}$ Interviews 4, 9, 16.

${ }^{114}$ Anonymised interview.

${ }^{115}$ Interviews 1, 2, 8, 16.

${ }^{116}$ Interview 1.

${ }^{117}$ Interviews 4, 6, 7, 10, 11.

${ }^{118}$ Interview 11.

${ }^{119}$ Tony Porter and Michael Webb, 'The Role of the OECD in the Orchestration of Global Knowledge Networks', paper for presentation at Canadian Political Science Association Annual Meetings Saskatoon, Saskatchewan, Canada (2007), p. 7. Lehtonen also notes that peer reviews can empower reform-oriented actors ('OECD Environmental Performance Review Programme').

${ }^{120}$ Interviews 4,5 .
} 
Yet, these newly acquired skills and networks are partially inconsequential, when insufficient human and financial resources are made available to put them into practice. ${ }^{121}$ While none of the interviewed delegates reported to find their obligations under the Convention unclear, capacity and resource constraints pose significant challenges. ${ }^{122}$ Cross-border investigations can take a long time and are often complex, ${ }^{123}$ while in some states personnel working on foreign bribery are limited, ${ }^{124}$ law enforcement agencies are underfunded, ${ }^{125}$ and the workload for prosecutors and judges is high. Due to limited resources, choices have to be made as to which alleged foreign bribery cases will be investigated. ${ }^{126}$ This poses particular problems in times of economic downturn, when the amount of public funds that can be put towards detecting, investigating, and prosecuting foreign bribery decreases. ${ }^{127}$

It would be premature, however, to conclude that non-compliance is primarily due to resource and capacity constraints. Interviews suggest that in many countries foreign bribery is not a political priority. ${ }^{128}$ Several delegates mentioned how foreign bribery has moved down on their government's priority lists, ${ }^{129}$ making it more difficult to mobilise support and resources to investigate suspected foreign bribery cases. As one of them summed up the political attitude to foreign bribery: 'there is no interest in it, it is not a priority, and there are other things that have to be done'. ${ }^{130}$ Rather than spending resources, time, and energy on fighting a crime that is often not visible to the public, several governments focus on tackling other forms of crime, instead. ${ }^{131}$ In many Phase 3 evaluation reports, the WGB then also demands that states make adequate resources available to proactively fight this crime. While peer review processes aimed at learning and capacity building can contribute to compliance, there has to be some degree of political will for them to be effective.

\subsection{Summary}

'At the end of the day, it is all about political will.'132 This view, expressed by a state delegate, was shared by many other participants in the WGB. Peer review may be capable of creating transparency, generating peer pressure, mobilising public pressure, and stimulating learning. Yet, as long as political support for sanctioning foreign bribery is low, the instrument is constrained in its capacity to engender reform on the ground. These findings correspond to observations on reviewing bodies in the area of human rights, ${ }^{133}$ and on the implementation of the OECD DAC principles in South Korea. ${ }^{134}$

Today, several WGB member states still lack strong incentives to investigate and prosecute foreign bribery. While in some states this may be due to a small export sector, which lowers their risk

\footnotetext{
${ }^{121}$ Instances were learning stays at the level of the individual but does not trickle down to national administrations (that is, 'blocked learning') have also been discussed in the context of the Open Method of Coordination, an EU peer review; Vagionaki, 'Blocked learning in Greece'.

${ }^{122}$ Interviews $1,2,4,9,12$.

${ }^{123}$ Interview 1.

${ }^{124}$ Interviews 1,4

${ }^{125}$ Interview 12.

${ }^{126}$ Interviews $1,9$.

${ }^{127}$ Interviews 2, 4, 12; interview 1 also mentioned that the economic crisis might have changed their government's political priorities.

${ }^{128}$ Interviews 9, 10, 11, 12; interviews 4, 16, 17 made similar remarks with reference to other states.

${ }^{129}$ Interviews $1,6,9$.

${ }^{130}$ Interview 9; also 10.

${ }^{131}$ Policy areas that receive more attention include fraud, domestic forms of corruption, cybercrime, terrorism, money laundering, and violent crime; interviews $2,6,14$.

${ }^{132}$ Interview 2; also 1, 4, 9, 14; in addition, several delegates mentioned that who is in charge politically matters; $1,8,14,17$.

${ }^{133}$ Carraro concludes that: 'Helping states to comply by means of learning and providing clear guidelines is not sufficient when political willingness is lacking' (p. 11; 'Promoting compliance with human rights').

${ }^{134}$ Lim, 'Compliance with international norms'.
} 
profile to foreign bribery, many countries with sizable and thriving export markets do not actively enforce the Convention either. Research by Jo-Anne Gilbert and J. C. Sharman shows that in the past, several governments have resisted compliance with the Anti-Bribery Convention, driven by electoral incentives to (appear to) protect business interests. ${ }^{135}$ As long as several large, exporting economies do not prosecute companies that pay bribes abroad, the playing field is not levelled and unfair competition prevails. ${ }^{136}$ Thus, on its own, peer review might not suffice to solve this collective action problem.

What are the theoretical implications of these findings? When it comes to reasons for noncompliance, the findings mainly correspond to an enforcement perspective, which asserts that states will comply with an international agreement when the benefits of compliance outweigh its costs. Interviews additionally suggest that low compliance activity is due to capacity and resource constraints, which corresponds to a management perspective. However, lack of capacity appears to be intertwined with lack of political will; how many personnel and resources states allocate to fighting foreign bribery is often (though not always) a political choice.

How about the policy interventions suggested by these theoretical schools? The policy solutions put forward by enforcement theorists, such as (soft) sanctioning in the form of peer and public pressure, help to raise awareness among investigators and prosecutors of foreign bribery, and create reputational costs. While these processes may have promoted some reforms in states, they are unlikely to tilt the balance towards full compliance on their own. The instances in which they appear most effective often coincide with the exposure of a corruption scandal or with the installation of a government that is more positively predisposed to fighting corruption. Once states are, in principle, willing to comply, the policy interventions suggested by the management school and constructivism (such as learning and international cooperation) become more important. These processes help to build capacity in states and foster skills and networks that are pivotal for detecting, investigating and sanctioning foreign bribery. The different peer review processes should therefore be seen as complementary; peer reviews might be most consequential when they can effectively deploy and combine these processes to address different barriers to state compliance. ${ }^{137}$

\section{Conclusion}

Are peer reviews at all relevant for addressing transnational policy problems, such as foreign bribery? This article discussed three ways in which peer reviews can contribute to compliance with international anti-corruption norms: (1) by creating transparency about state behaviour; (2) by mobilising pressure on recusant states; and by (3) promoting learning and capacity building. Specifically, it analysed to what extent one such peer review (the OECD WGB) is perceived as capable of organising these processes, and how far participants in this peer review regard these processes as relevant for compliance.

To answer these questions, this article first developed a theoretical framework detailing the processes and mechanisms through which peer reviews were expected to contribute to compliance. This framework was inspired by three schools in the compliance literature - the enforcement, management, and constructivist schools - and existing research on peer reviews. Based on evidence from an online survey and semi-structured interviews, the empirical analysis shows that the WGB is indeed perceived as rather effective in creating transparency, organising pressure, and stimulating learning. Yet, the extent to which these processes can produce reform on the ground appears to be more limited and largely dependent on political will.

\footnotetext{
${ }^{135}$ Jo-Anne Gilbert and J. C. Sharman, 'Turning a blind eye to bribery: Explaining failures to comply with the international anti-corruption regime’, Political Studies, 46:1 (2014), pp. 74-89.

${ }^{136}$ This not only applies to the WGB members that do not actively enforce the Convention, but also to several nonsignatory states with large export markets; interviews $1,3,8,11,14$.

${ }^{137}$ Delegates also mentioned how different peer review processes can be combined: for example, peer pressure and international cooperation (interview 1) and peer pressure and capacity building (interview 14).
} 
Enforcement scholars expect that states will comply with international norms, when the benefits of compliance outweigh its costs. The findings of this article largely confirm this expectation. From earlier research, we already knew that several governments are disinclined to comply with the Anti-Bribery Convention. ${ }^{138}$ Similar considerations were raised in interviews conducted for this article: The perception that compliance harms business interests, the lack of interest in and awareness of foreign bribery in some states, and the efforts and resources that need to go into transnational bribery investigations, all raise the costs of compliance. Peer and public pressure are perceived to create awareness among law enforcement authorities of this crime and to impose material and social costs on states, such as having to redo an evaluation or negative media publicity. Even though these processes have triggered some change, these costs often do not outweigh the benefits of non-compliance. Furthermore, although many state delegates feel personally under pressure to take action, this pressure does not always trickle down to all responsible departments and actors.

While enforcement theorists offer the most compelling explanation for why states do (not) comply with anti-bribery legislation, this does not mean that we should refute the compliance strategies put forward by the management and constructivists schools. Political will might be crucial for compliance, but compliance is not only a matter of political will. Interviews indicate that states that are willing to fight foreign bribery benefit from the exchange of information as well as from the opportunities peer review offers for developing networks and personal relationships. Peer review processes aimed at promoting (social) learning, international networking, and capacity building are important in this regard. Sustained peer and public pressure, in turn, helps keep foreign bribery on the political agenda and gives much needed support to reform-oriented actors that are presently facing domestic resistance. This underscores that we should not assess peer reviews only in terms of their ability to trigger compliance, but also the extent to which they set in motion processes that contribute to state compliance in more indirect ways and over longer periods of time. ${ }^{139}$

In light of the above findings, this article echoes earlier calls to treat the three compliance logics as complementary. ${ }^{140}$ Several scholars have previously recognised that no compliance logic can account for states' behaviour on its own; in order to understand variation in compliance levels across states, we need to combine these three analytical perspectives. The findings of this article additionally suggest that reasons for (non-)compliance not only vary across states but might even differ within states over time. It is therefore important to consider how different compliance strategies - and by extension peer review processes $^{141}$ - can be combined to effectively promote compliance.

To conclude, what do these findings tell us about peer review as a mode of governance in the anti-corruption regime? As the oldest and most developed peer review in the anti-corruption regime, the WGB is a most-likely case to promote anti-corruption reforms. If the WGB faces challenges in promoting compliance, other peer reviews most likely do so as well. Of course, a single case study has its limitations. The WGB deals with fighting transnational corporate bribery. As argued earlier, this type of corruption is often not top of the political agenda and tends to garner limited public interest. In addition, the WGB brings together a fairly homogeneous group of industrialised states. Other peer reviews, which bring together a more diverse group of states, might face different or additional challenges when trying to promote compliance. Finally, this article only analysed the perceptions of individuals who participate in a peer review, many of which share responsibility for enforcing the Convention. They are, however, not the only

\footnotetext{
${ }^{138}$ Gilbert and Sharman, 'Turning a blind eye to bribery'.

${ }^{139}$ This corresponds to what Hale refers to as the 'compliance plus perspective' ('Under what conditions', p. 6).

${ }^{140}$ Börzel et al., 'Obstinate and insufficient'; Carraro, 'Promoting compliance with human rights'; Hartlapp, 'On enforcement'; Tallberg 'Paths to compliance'; Versluis and Tarr, 'Improving compliance'.

${ }^{141}$ Lehtonen also concludes that policy learning and accountability can be complementary in a peer review ('OECD Environmental Performance Review Programme').
} 
responsible actors. An assessment of how political actors perceive compliance with the Convention, as well as their awareness of the WGB, provides an important avenue for future research.

Acknowledgements. I would like to thank Valentina Carraro, Johan Karlsson Schaffer, Camilla Orjuela, Kilian Spandler, Fredrik Söderbaum, the two anonymous reviewers, and participants in the B\&P Young Scholars Research Seminar and the Quality of Governance group at the Vrije Universiteit Amsterdam for their helpful feedback on earlier drafts. Part of the research for this article was carried out in the project 'No Carrots, No Sticks: How Do Peer Reviews Among States Acquire Authority in Global Governance?', led by Thomas Conzelmann at Maastricht University. This project received funding from the Dutch Research Council (Grant No. 452-11-016).

Hortense Jongen is an Assistant Professor in International Relations at the Vrije Universiteit Amsterdam. Her research focuses on legitimacy and authority in new modes of global governance, with a specific interest in the global fight against corruption and Internet governance. Her research has been published in Cooperation and Conflict; Global Governance; and Review of International Political Economy.

\section{Appendix}

\section{Interviews ${ }^{142}$}

1: Delegate, Western Europe, in person, 9 January 2014.

2: Delegate, Western Europe, in person, 10 January 2014.

3: Delegate, Western Europe, in person, 16 January 2014.

4: OECD Secretariat, in person, 26 March 2014.

5: OECD Secretariat, in person, 27 March 2014.

6: Delegate, Central/Eastern Europe, by telephone, 15 May 2015.

7: Delegate, Western Europe, in person, 16 June 2015.

8: Delegate, Western Europe, by telephone, 5 August 2015.

10: Delegate, Africa/Americas/Asia, by telephone, 12 August 2015.

11: Delegate, Central/Eastern Europe, by telephone, 13 August 2015.

12: Delegate, Africa/Americas/Asia, by telephone, 21 August 2015.

13: Delegate, Western Europe, via Zoom, 21 October 2020.

14: Delegate, Western Europe, via Skype, 23 October 2020.

15: Delegate, Africa/Americas/Asia, via Zoom, 26 October 2020.

16: Delegate, Western Europe, by telephone, 3 November 2020.

17: Delegate, Western Europe, via Zoom, 5 November 2020.

\section{Pearson product-moment correlations}

\begin{tabular}{|c|c|c|c|c|c|c|c|c|}
\hline & 2 & 3 & 4 & 5 & 6 & 7 & 8 & 9 \\
\hline 1 Transparency & .089 & .116 & $.305^{\star}$ & -.100 & .171 & -.140 & .200 & .117 \\
\hline 2 Peer pressure & & $.432^{\star \star \star}$ & .196 & $.288^{\star}$ & .229 & .156 & .145 & .029 \\
\hline 3 Public pressure & & & .133 & .063 & .196 & .025 & $.256^{\star}$ & -.025 \\
\hline 4 Feeling under pressure & & & & -.036 & .213 & -.110 & -.093 & .180 \\
\hline 5 Accuracy of output & & & & & $.410^{\star \star \star}$ & $.464^{\star \star \star}$ & $.287^{\star}$ & -.198 \\
\hline 6 Mutual learning & & & & & & $.310^{\star \star}$ & $.321^{\star \star}$ & -.219 \\
\hline 7 Technical assistance & & & & & & & $.426^{\star \star \star}$ & $-.247^{\star}$ \\
\hline 8 International cooperation & & & & & & & & -.141 \\
\hline 9 Legitimacy perceptions & & & & & & & & \\
\hline
\end{tabular}

Notes: $\mathrm{p}<0.05 ; \mathrm{p}<0.01 ; \mathrm{p}<0.001$.

\footnotetext{
${ }^{142}$ The classification 'Africa/Americas/Asia is used to protect the anonymity of interviewees. As relatively few African, American and Asian states participate in the WGB, I cannot break down the interviewees by region.

Cite this article: Jongen, H. 2021. Peer review and compliance with international anti-corruption norms: Insights from the OECD Working Group on Bribery. Review of International Studies 47, 331-352. https://doi.org/10.1017/S0260210521000097
} 